\title{
Effect of Integrated Nutrient Management on Growth and Yield Attributing Parameters of Cucumber (Cucumis sativus L.) under Protected Condition
}

\author{
Sudeshna Kharga*, Pranabjyoti Sarma, S.D. Warade, P. Debnath, L. Wangchu, \\ Amit Kumar Singh and Akhoki G. Simray
}
College of Horticulture and Forestry, Central Agricultural University, Pasighat-791102, Arunachal Pradesh, India

*Corresponding author

\begin{tabular}{|l|}
\hline Ke y w o r d s \\
$\begin{array}{l}\text { Cucumber, } \\
\text { gynoecious, Protected } \\
\text { cultivation, Integrated } \\
\text { nutrient management, } \\
\text { Growth, Yield }\end{array}$ \\
\hline Article Info \\
\hline $\begin{array}{l}\text { Accepted: } \\
\text { 15 July 2019 } \\
\text { Available Online: } \\
\text { 10 August } 2019\end{array}$ \\
\hline
\end{tabular}

\section{Introduction}

Cultivated cucumber is botanically known as Cucumis sativus $\mathrm{L}$. and is native to India. It has the diploid chromosome number of $2 \mathrm{n}=14$ and Cucumis hardwickii is the probable progenitor of cultivated cucumber, which is small bitter cucumber with sparse and stiff spines and are generally found in abundance
The experiment was conducted at College of Horticulture and Forestry, Central Agricultural University, Pasighat, Arunachal Pradesh to study the effect of integrated nutrient management on growth and yield of cucumber (Cucumis sativus L.) grown under protected condition. It was laid out in Randomized Block Design comprising of thirteen treatments replicated thrice. The experiment was conducted during the off season with gynoecious hybrid variety KSP-1301. Integration of inorganic fertilizers, organic manures and biofertilizers has increased the efficacy of the nutrients in the soil. Integration of vermicompost with inorganic fertilizers and microbial inoculants has efficiently contributed in mineralisation of unavailable forms of nutrient to the available form. The results revealed that the vines of cucumber fertilized with $\mathrm{T}_{5}(75 \%$ of RDF of NPK + vermicompost @ $7.5 \mathrm{t} / \mathrm{ha})$ recorded maximum vine length $(190.26 \mathrm{~cm})$, number of branches per plant (12.97) and internodal length $(13.86 \mathrm{~cm})$. However, the superior response in terms of flowering and the yield attributing parameters like minimum days to $50 \%$ flowering (34.01), minimum days to $50 \%$ fruiting (45.01), fruit length $(16.20 \mathrm{~cm})$, fruit breadth $(4.21 \mathrm{~cm})$, fruit girth $(13.18 \mathrm{~cm})$, fruit weight $(197.39 \mathrm{~g})$, yield of fruits per vine $(1.75 \mathrm{~kg})$, yield of fruits per plot $(12.43 \mathrm{~kg})$, number of fruits per vine $(10.81)$, number of fruits per plot (91.51) and total yield $(287.89 \mathrm{q} / \mathrm{ha})$ was recorded from $\mathrm{T}_{13}(50 \%$ of RDF of NPK + vermicompost @ 5 t/ha + Azotobacter @ 5 kg/ha + PSB @ 5 kg/ha).

in the foothills of Himalayas (Singh, 2013). Cucumber is an annual creeping vine that grows by dint of the supporting frames and wrapping around with its spiralling tendrils. The plants grow to a towering height and leaves are large hairy triangular, ovate or somewhat cordate, $7-20 \mathrm{~cm}$ in length. Cucumber is predominantly monoecious which means it bears staminate and pistillate 
flowers separately on the same vine however the other sex forms like androecious, gynoecious, hermaphrodite and andromonoecious has also been reported in cucumber (Bailey, 1929). Staminate flower appears a week earlier than the pistillate flower. Flowers are yellow in colour and pollination is mediated by bees and other insects. Female flowers are recognized as it bears swollen ovary (resembles miniature fruit) at the base which will later develop into the edible fruits. Fruit of cucumber is botanically known as pepo. It is elongated and round to triangular in shape and the skin colour may vary from pale green to dark green. The fruit has high water content of about $95 \%$. Many seeds are produced inside the single fruit, which are flat with pointed ends on both the sides, white to pale white in colour, $8-10 \mathrm{~mm} \times 3-5 \mathrm{~mm}$ and the test weight of the seed is $20 \mathrm{~g}$ (Singh and Bahadur, 2015). Being one of the popular members of gourd family, it is commercially cultivated for its immature and tender cylindrical fruits. Bitterness at the stem ends of cucumber fruits, usually discarded before eating, is due to the presence of bitter principle known as cucurbitacins which is tetracyclic triterpenes. Hence, metaxenia is a common phenomenon observed in cucumber and bitter gourd which is due to the presence of bitter pollen grains which fertilizes non bitter or normal ovule ultimately resulting in development of bitter fruits (Selvakumar, 2014). Cucumber is widely grown for salad purpose and due to the realization of their importance in our daily diet the demand has been increasing presently. Edible portion of cucumber is enriched with $0.4 \%$ protein, $2.5 \%$ carbohydrates, $0.1 \%$ fat, $7.0 \mathrm{mg}$ vitamin $\mathrm{C}, 25 \mathrm{mg}$ phosphorus, $124 \mathrm{mg}$ of potassium, $10 \mathrm{mg}$ calcium and $1.5 \mathrm{mg}$ iron per $100 \mathrm{~g}$ edible fruit (Singh et al., 2018). Cucumber fruits have diuretic property, due to the high water content of about $95 \%$ which helps to keep the body hydrated and helps in eliminating all the toxins present in the body.
It is used as a remedy for preventing constipation, jaundice and indigestion (Singh et al., 2017). Being a thermophilic crop, cucumber requires a warm climatic condition with abundant sunlight. They are highly susceptible to low temperature and require frost free environmental condition for their cultivation. Hence, their cultivation is restricted during winter season as they require high temperature (usually about 28$30^{\circ}$ Celcius) for their growth and development. However, the cultivation of cucumber can be made feasible during winter season under the protected condition. Protected cultivation of vegetable has emerged as an alternate production technology to overcome several biotic and abiotic stresses and to break the seasonal barrier to production. It gives a boost to the nutrient and irrigation use efficiency along with the proper utilization of natural resources. This technology is being employed popularly for the year round and off season production of high value commercial crops like capsicum, tomato and cucumber. Success in the cultivation of cucumber under polyhouse condition during the off season can be achieved by the use of suitable cucumber hybrid like parthenocarpic variety or gynoecious hybrid along with adequate incorporation of nutrient which becomes indispensable for the growth and development. An adequate supply of nutrient is another important factor for increasing the crop productivity in high value crop like cucumber. Presently, INM (integrated nutrient management) is gaining more importance as it ensures scientific management of soil health for optimum growth, yield and quality of crops in a sustainable manner. Excessive application of chemical fertilizer alone has adverse impact on the environment as it causes deterioration of soil health and the consumption of these inorganic products may jeopardize our health. Organic manures on the other hand are bulky in nature and has less analytical value due to its low nutrient content. 
There always runs a risk of low yield associated with organic manures which will not fulfil the food requirement of densely populated country like India as they are slow nutrient releasing fertilizer if they are applied without integration with inorganic source. Organic manures being bulky by nature has less amount of major nutrients as compared to the chemical fertilizers, however they are rich in growth promoting hormones and beneficial enzymes and vitamins which makes them a preferential choice for enhancing the soil fertility and crop yield (Bhuma, 2001). Application of biofertilizers on the other hand avails the soil of increasing microbial population, which ultimately aggrandize the decomposition rate, productivity and sustainability of the soils. They cater organic acids that help to dissolve soil nutrients and make them available to the plants. Therefore, encouraging the use of organic manure in combination with inorganic fertilizers along with biological components appears to be the best substitute in present situation. INM is a sustainable approach, which aims at maintaining the soil fertility and plant nutrient supply, by incorporating all the possible sources of nutrients like organic manures, inorganic fertilizer and the biological components in an integrated and judicious manner to get higher crop yield without in anyway hampering the soil health and the environment. The integration of different nutrient sources enhances growth, yield and quality attributing characters in vegetables as compared with sole application of recommended dose of chemical fertilizers, making integrated nutrient management practice both innovative and environment friendly for sustainable growth, yield and quality of vegetables (Kumar et al., 2018). The reduction of micronutrient deficiencies in Indian soil with efficient utilization of natural resources and recycling of agricultural waste and ameliorated microbial activity in the soil resulting in higher crop productivity are some of the advantages associated with INM (Johan et al., 2001). The goal of INM is to integrate the use of natural and human made sources of plant nutrients to aggrandize agricultural productivity in an efficient and environmental friendly manner without diminishing the production capacity of soil for present and future generations (Dinesh and Yadav, 2000). Combined application of organic manure and chemical fertilizer strongly influenced growth parameters and plants supplied with 100\% RDF (recommended dose of fertilizers) of $\mathrm{N}$ (Nitrogen), P (Phosphorus) and K (Potassium) + FYM (farm yard manure) @ 10 t/ha + vermicompost @5t/ha + poultry manure @ $2.5 \mathrm{t} / \mathrm{ha}$ was witnessed to be the best integrated nutrient treatment and gave the highest yield in bottle gourd (Baghel et al., 2017).

\section{Materials and Methods}

The present experiment entitled "Influence of Integrated Nutrient Management on Growth and Yield Attributing Parameters of Cucumber (Cucumis sativus L.) under Protected Condition" was conducted at College of Horticulture and Forestry, Central Agricultural University, Pasighat, Arunachal Pradesh during the session of 2017-2018. The experiment was laid out in Randomised Block Design comprising of thirteen treatments replicated thrice. Treatment of cucumber vines with the integration of various organic manures, inorganic fertilizers and biofertilizers has been done in this experiment with the view of standardization of suitable nutrient combination under integrated nutrient management practice for growing cucumber under protected condition. Two most important organic manures namely FYM and vermicompost along with inorganic fertilizers like urea, SSP and MOP and biofertilizer i.e. Azotobacter and PSB has been used in various combination to study the effect of integrated nutrient management on growth and yield of 
cucumber. The treatment details are $\mathrm{T}_{1}(\mathrm{RDF}$ of NPK@150:120:120 kg/ha +FYM @15 t/ha), $\mathrm{T}_{2}(75 \%$ of RDF of NPK + FYM @ 20 t/ha), $T_{3}(75 \%$ of RDF of NPK + FYM @ 15 t/ha + Azotobacter @ $5 \mathrm{~kg} / \mathrm{ha}), \mathrm{T}_{4}$ (75\% of RDF of NPK + FYM @ 10 t/ha + Azotobacter @ $5 \mathrm{~kg} / \mathrm{ha}+\mathrm{PSB} @ 5 \mathrm{~kg} / \mathrm{ha}), \mathrm{T}_{5}(75 \%$ of RDF of NPK + vermicompost @ $7.5 \mathrm{t} / \mathrm{ha}), \mathrm{T}_{6}$ (75\% of RDF of NPK + vermicompost @ 5 t/ha + Azotobacter @ 5 kg/ha), $\mathrm{T}_{7}$ (75\% of $\mathrm{RDF}$ of NPK + vermicompost @ $2.5 \mathrm{t} / \mathrm{ha}+$ Azotobacter @ $5 \mathrm{~kg} / \mathrm{ha}+\mathrm{PSB} @ 5 \mathrm{~kg} / \mathrm{ha}), \mathrm{T}_{8}$ (50\% of RDF of NPK + FYM @ $30 \mathrm{t} / \mathrm{ha}$ ), $\mathrm{T}_{9}$ (50\% of RDF of NPK + FYM @ 25 t/ha + Azotobacter @ $5 \mathrm{~kg} / \mathrm{ha}), \mathrm{T}_{10}(50 \%$ of RDF of NPK + FYM@20 t/ha + Azotobacter@5 $\mathrm{kg} / \mathrm{ha}+$ PSB @ $5 \mathrm{~kg} / \mathrm{ha}), \mathrm{T}_{11}(50 \%$ of RDF of NPK + vermicompost @ 10 t/ha), $\mathrm{T}_{12}(50 \%$ of RDF of NPK + vermicompost @ 7.5 t/ha + Azotobacter@ $5 \mathrm{~kg} / \mathrm{ha})$ and $\mathrm{T}_{13}(50 \%$ of RDF of NPK + vermicompost @ 5 t/ha + Azotobacter@5 kg/ha +PSB @ 5 kg/ha).

Seedlings were first raised in the polybags filled with media containing sterilised soil, FYM and sand in the ratio of 2:1:1. Single seed was sown on $21^{\text {st }}$ October 2017 in each polybag. Adequate care with regular monitoring of the seedlings was done to prevent the mortality at the nursery stage. Regular watering and necessary plant protection measures were adopted to ensure the healthy growth of seedlings. Seedlings became ready for transplanting within 15-20 days after sowing. Application of fertilizers was done depending upon the treatment allotted to the different experimental plots. Well decomposed organic manures (FYM and vermicompost) and inorganic fertilizers (urea, SSP and MOP) were added and mixed thoroughly with the soil at the time of bed preparation while the pit application of biofertilizers (Azotobacter and PSB) was done later at the time of transplanting of seedlings. Required quantity of fertilizers was measured using a weighing balance and was incorporated to the experimental plots as per the treatment allotted. 20 days old seedlings preferably at 2-3 leaf stage were transplanted on $10^{\text {th }}$ November 2017 with the spacing of 60 $\mathrm{cm} \times 60 \mathrm{~cm}$ in the pits. Transplanting was done in the evening by making a vertical incision in the polybags to remove the seedlings without disturbing the roots and was carefully transplanted to the nursery bed of 3.6 $\mathrm{m} \times 1.2 \mathrm{~m}$ size. Twelve numbers of plants were accommodated in a single plot. During the experimentation, various observations on growth and yield parameters were recorded. The data obtained were statistically analysed using standard statistical procedures as suggested by Gomez and Gomez (2010) and also by using online OPSTAT software.

\section{Results and Discussion}

\section{Effect of integrated nutrient management on growth parameters of cucumber}

Data illustrated in table 1 indicated that there was a significant influence on vegetative parameters of cucumber viz. vine length $(\mathrm{cm})$, internodal length $(\mathrm{cm})$ and number of branches per plant under integrated nutrient management approach. It was revealed that the vines of cucumber fertilized with $\mathrm{T}_{5}(75 \%$ of RDF of NPK + vermicompost @ $7.5 \mathrm{t} / \mathrm{ha}$ ) recorded maximum vine length $(190.26 \mathrm{~cm})$, internodal length $(13.86 \mathrm{~cm})$ and number of branches per plant (12.97). Experimental findings related to growth parameters as tabularised and depicted in table 1 further revealed that $T_{5}$ was at par with $T_{1}$ for internodal length and with $T_{1}$ and $T_{2}$ for number of branches per plant. However, the minimum response in terms of vine length $(160.16 \mathrm{~cm})$, internodal length $(10.40 \mathrm{~cm})$ and minimum number of branches per vine (8.51) was witnessed in $\mathrm{T}_{8}(50 \%$ of RDF of NPK + FYM @ 30 t/ha). Enhanced vegetative parameters in $\mathrm{T}_{5}$ may be attributed to the usage of high concentration of nitrogenous 
fertilizers which are made readily available to plants through inorganic source. Application of high dose of nitrogenous fertilizers resulted in maximum nutrient uptake by plants inducing vigorous vegetative growth due to the instant availability of nutrients to vines through inorganic fertilizers. Adequate supply of nitrogen to vines resulted in sufficient release of amino acids which are the polymers of protein and significantly increased the rate of cell division in apical shoots and accelerated the meristematic activity thereby manifesting enhanced vegetative characters in the vines treated with $\mathrm{T}_{5}$. Increase in vine length and internodal length may be due to the rapid multiplication of cell which causes the cells to elongate along the main axis. The findings are in congruence with Bindiya (2004) and Anjanappa et al., (2012) in cucumber, Baghel et al., (2017) and Patle et al., (2018) in bottle gourd and Rathod et al., (2018) in ridge gourd. Another probable reason for increase in vegetative parameters may be due to the judicious integration of vermicompost in combination with inorganic fertilizers in $\mathrm{T}_{5}$, which has proven to increase the nutrient use efficiency of the vines. The result complies with the findings given by Rekha and Gopalakrishnan (2001) in bitter gourd and Singh et al., (2018) in cucumber. Incorporation of vermicompost in combination with inorganic fertilizers are known to increase the population of beneficial microorganism and has proven to improve the soil biological properties. Beneficial microorganisms present in vermicompost are prerequisite as they are responsible for accelerating the rate of decomposition for efficient and rapid release of available form of nutrients from organic manures. The fertilization of experimental plot with integrated nutrient management approach may be attributed to offer suitable growing media providing better aeration with ample amount of organic matter in the soil creating perfect microclimatic condition for the growth of crop raised under protected structure to develop effective crop stand at the vegetative stage. Mahmoud et al., (2009) studied the influence of integrated nutrient management on growth of cucumber and mentioned the similar findings.

\section{Effect of integrated nutrient management on flowering and yield attributing parameters of cucumber}

Integration of inorganic fertilizers, organic manures and biological components reflected the significant differences on various flowering and yield attributing parameters of cucumber. However, no significant difference was observed on fruit breadth of cucumber under integrated nutrient management approach. Tabularised data from table 2 depicted that the superior response in terms of flowering and the yield attributing parameters like minimum number of days to $50 \%$ flowering (34.01), minimum number of days to $50 \%$ fruiting (45.01), fruit length (16.20 $\mathrm{cm})$, fruit breadth $(4.21 \mathrm{~cm})$, fruit girth $(13.18$ $\mathrm{cm})$, fruit weight $(197.39 \mathrm{~g})$, yield of fruits per vine $(1.75 \mathrm{~kg})$, yield of fruits per plot $(12.43$ $\mathrm{kg}$ ), number of fruits per vine (10.81), number of fruits per plot (91.51) and total yield (287.89 q/ha) was recorded from $\mathrm{T}_{13}(50 \%$ of $\mathrm{RDF}$ of NPK + vermicompost @ 5 t/ha + Azotobacter@5 kg/ha + PSB @ 5 kg/ha). Least number of days to $50 \%$ flowering and fruiting in $\mathrm{T}_{13}$ may be attributed to the fact that the judicious integration of organic manures with inorganic fertilizers and biofertilizers are capable of supplying optimum level of nutrient along with favourable growing media efficient in inducing early flowering in the very treatment. These results are in close conformity with the experimental findings of Vishwakarma et al., (2007) in spine gourd, Mohan et al., (2016) and Singh et al., (2018) in cucumber. It might also be due to the better nitrogen fixation and phosphorus solubilisation mediated by the 
Azotobacter and PSB which are responsible for transforming the unavailable form of nutrient present in the soil to the available form. The findings are in resemblance with the reports given by Prasad et al., (2009) in bitter gourd and Baghel et al., (2017) in bottle gourd. Vermicompost being a rich source of micro nutrients like $\mathrm{Zn}, \mathrm{Fe}, \mathrm{Cu}$ and $\mathrm{Mn}$ are involved in synthesis of plant hormones like auxin (IAA) through tryptophan pathway. Further, vitamins, minerals and phytohormones like auxin and other growth regulators present in vermicompost might be the probable reason for inducing ample number of functional female flowers in $T_{13}$. The experimental findings are well supported by the findings given by Sreenivas et al., (2000) in ridge gourd, Kameswari et al., (2010) in ridge gourd and Anjanappa et al., (2012) in cucumber. Least number of days to $50 \%$ fruiting recorded in $\mathrm{T}_{13}$ which was at par with $\mathrm{T}_{7}$ might be due to the excellent blending of inorganic fertilizers with organic manures and biological components. It might have facilitated the adequate supply of nutrient to the soil making it available to the plants for early flowering and fruiting. Use of biofertilizers like Azotobacter and PSB has further contributed in nutrient fixation and solubilisation and has efficiently increased the soil biological properties. This may be because of the presence of organic acids, enzymes and phytohormones like auxins and other growth regulators in vermicompost which are indispensable for early fruiting. The results are in consonance with the findings of Arshad et al., (2014) and Moharana et al., (2017) in cucumber.

Yield attributing parameters like fruit length, fruit breadth, fruit girth and fruit weight were superior in $\mathrm{T}_{13}$ and was at par with $\mathrm{T}_{7}$ as illustrated from the table 2. Superior fruit length, fruit breadth, fruit girth and fruit weight may be because of the easy accessibility of nutrients to plants through inorganic fertilizers along with better solubilisation of organic manures with the action of Azotobacter and PSB. Integration of biological components like Azotobacter with inorganic fertilizers and organic manures has proven to enhance the process of nitrogen fixation in the soil. The findings are in congruence with Mulani et al., (2007) in bitter gourd and Nayak et al., (2016) in pointed gourd. It has further resulted in the production of amino acids which are the building blocks of protein capable of hastening the multiplication of cells manifesting maximum fruit length, breadth, girth and weight. The findings are in congruence with results provided by Prabhu et al., (2006), Jilani et al., (2009), Arun and Kumar (2014) and Singh (2016) in cucumber. One of the probable reasons behind improved fruit characteristics may be due to the production and translocation of adequate amount of photosynthates from leaves to the reproductive organs. These results are in consonance with the experimental findings of Eifediyi and Remison (2010), Ghasem et al., (2014) and Moharana et al., (2017) in cucumber.

Aggrandized yield in $\mathrm{T}_{13}$ may be caused due to an ample concentration of endogenous plant growth regulators like auxin, vitamins and mineral in vermicompost which may have contributed to superior fruit characteristics encouraging more number of fruits per vine in $\mathrm{T}_{13}$. Endogenous auxins are known to stimulate more number of female flowers in the vines subsequently resulting in maximum fruit yield. The results are in close conformity with the findings of Kameswari et al., (2010). Higher yield per vine may be due to the role of biological components like Azotobacter in faster nitrogen fixation and PSB in phosphorus solubilisation in combination with the quick release of available nutrient from the inorganic fertilizers coupled with micronutrients and vitamins from organic manures like vermicompost. 
Table.1 Effect of integrated nutrient management on growth parameters of cucumber

\begin{tabular}{|c|c|c|c|}
\hline Treatments & Vine length $(\mathbf{c m})$ & Internodal length $(\mathbf{c m})$ & Number of branches per plant \\
\hline $\mathbf{T}_{\mathbf{1}}$ & 186.63 & 13.76 & 12.65 \\
\hline $\mathbf{T}_{\mathbf{2}}$ & 185.23 & 13.46 & 12.59 \\
\hline $\mathbf{T}_{\mathbf{3}}$ & 179.96 & 12.30 & 11.17 \\
\hline $\mathbf{T}_{\mathbf{4}}$ & 169.20 & 10.80 & 9.76 \\
\hline $\mathbf{T}_{\mathbf{5}}$ & 190.26 & 13.86 & 12.97 \\
\hline $\mathbf{T}_{\mathbf{6}}$ & 180.26 & 12.33 & 12.48 \\
\hline $\mathbf{T}_{\mathbf{7}}$ & 178.00 & 11.80 & 10.01 \\
\hline $\mathbf{T}_{\mathbf{8}}$ & 160.16 & 10.40 & 8.51 \\
\hline $\mathbf{T}_{\mathbf{9}}$ & 172.96 & 11.03 & 9.85 \\
\hline $\mathbf{T}_{\mathbf{1 0}}$ & 162.96 & 10.63 & 9.07 \\
\hline $\mathbf{T}_{\mathbf{1 1}}$ & 175.96 & 11.36 & 9.94 \\
\hline $\mathbf{T}_{\mathbf{1 2}}$ & 165.10 & 10.70 & 9.18 \\
\hline $\mathbf{T}_{\mathbf{1 3}}$ & 178.20 & 11.96 & 10.83 \\
\hline $\mathbf{S E}(\mathbf{d})$ & 1.571 & 0.169 & 0.221 \\
\hline $\mathbf{C . D}$ at 5\% & 3.262 & 0.351 & 0.459 \\
\hline
\end{tabular}

Table.2 Effect of integrated nutrient management on flowering and yield attributing parameters of cucumber

\begin{tabular}{|c|c|c|c|c|c|c|c|c|c|c|c|}
\hline Treatments & $\begin{array}{c}\text { Days to } \\
50 \% \\
\text { flowering }\end{array}$ & $\begin{array}{c}\text { Days to } \\
50 \% \\
\text { fruiting }\end{array}$ & $\begin{array}{l}\text { Length } \\
\text { of fruit } \\
\text { (cm) }\end{array}$ & $\begin{array}{c}\text { Breadth } \\
\text { of fruit } \\
(\mathrm{cm})\end{array}$ & $\begin{array}{l}\text { Girth } \\
\text { of } \\
\text { fruit } \\
\text { (cm) }\end{array}$ & $\begin{array}{l}\text { Weight } \\
\text { of fruit } \\
\text { (g) }\end{array}$ & $\begin{array}{l}\text { Number } \\
\text { of fruits } \\
\text { per vine }\end{array}$ & $\begin{array}{l}\text { Number } \\
\text { of fruits } \\
\text { per plot }\end{array}$ & $\begin{array}{l}\text { yield } \\
\text { per } \\
\text { vine } \\
(\mathrm{kg})\end{array}$ & $\begin{array}{l}\text { yield } \\
\text { per } \\
\text { plot } \\
(\mathbf{k g})\end{array}$ & $\begin{array}{l}\text { yield } \\
\text { per } \\
\text { hectare } \\
\text { (q) }\end{array}$ \\
\hline $\mathbf{T}_{1}$ & 37.31 & 48.82 & 14.68 & 3.68 & 11.82 & 143.53 & 7.43 & 70.27 & 1.06 & 8.98 & 208.03 \\
\hline $\mathbf{T}_{2}$ & 37.84 & 49.32 & 14.62 & 3.63 & 11.48 & 137.27 & 7.40 & 70.20 & 1.04 & 8.58 & 197.61 \\
\hline $\mathbf{T}_{\mathbf{3}}$ & 36.91 & 48.71 & 14.71 & 3.78 & 11.86 & 146.65 & 7.54 & 70.63 & 1.07 & 9.75 & 225.85 \\
\hline $\mathbf{T}_{4}$ & 36.55 & 47.90 & 15.23 & 3.83 & 12.19 & 154.13 & 8.40 & 72.35 & 1.17 & 10.07 & 233.26 \\
\hline $\mathbf{T}_{5}$ & 36.00 & 47.19 & 15.44 & 3.92 & 12.40 & 163.85 & 8.63 & 85.25 & 1.30 & 10.46 & 242.29 \\
\hline $\mathbf{T}_{6}$ & 36.21 & 47.21 & 15.40 & 3.91 & 12.38 & 161.39 & 8.51 & 77.38 & 1.28 & 10.31 & 238.65 \\
\hline $\mathbf{T}_{7}$ & 34.99 & 46.01 & 15.88 & 4.14 & 12.78 & 176.17 & 9.90 & 87.60 & 1.51 & 11.79 & 273.07 \\
\hline $\mathbf{T}_{8}$ & 38.23 & 50.00 & 14.14 & 3.61 & 11.22 & 120.94 & 6.94 & 66.35 & 0.93 & 8.15 & 188.65 \\
\hline $\mathbf{T}_{9}$ & 36.79 & 48.38 & 14.83 & 3.80 & 12.06 & 152.87 & 7.57 & 71.41 & 1.14 & 9.95 & 230.32 \\
\hline $\mathbf{T}_{10}$ & 36.26 & 47.85 & 15.27 & 3.84 & 12.24 & 160.42 & 8.43 & 75.09 & 1.27 & 10.28 & 237.96 \\
\hline $\mathbf{T}_{11}$ & 35.97 & 47.06 & 15.49 & 3.96 & 12.50 & 171.97 & 9.05 & 85.26 & 1.35 & 10.74 & 248.61 \\
\hline $\mathbf{T}_{12}$ & 35.29 & 46.81 & 15.67 & 4.00 & 12.68 & 175.25 & 9.42 & 87.50 & 1.44 & 11.31 & 261.87 \\
\hline $\mathbf{T}_{13}$ & 34.01 & 45.01 & 16.21 & 4.21 & 13.18 & 197.39 & 10.81 & 91.51 & 1.75 & 12.43 & 287.89 \\
\hline SE(d) & 0.386 & 0.54 & 0.167 & 0.216 & 0.307 & 2.306 & 0.219 & 0.851 & 0.049 & 0.346 & 5.693 \\
\hline C.D at $5 \%$ & 0.802 & 1.122 & 0.347 & NS & 0.637 & 4.788 & 0.455 & 1.766 & 0.103 & 0.718 & 11.819 \\
\hline
\end{tabular}


The findings are in congruence with results provided by Sarhan et al., (2011) in summer squash, Isfahani and Besharati (2012), Thriveni et al., (2017) in bitter gourd, Ghayal et al., (2018) in cucumber. More number of fruits from the experimental plots treated with $\mathrm{T}_{13}$ may be because of the minimum number of days taken for female flower production apparently leading to highest number of fruits in $\mathrm{T}_{13}$.

Similar findings are quoted from the experimental trial conducted by Shreeniwas et al., (2000) in ridge gourd, Prabhu et al., (2006) and Narayanamma et al., (2010) in cucumber. Likewise, the possible reason behind maximum number of fruits resulting in highest fruit yield in $\mathrm{T}_{13}$ may be attributed to the minimum number of days taken for female flower emergence, allowing maximum number of female flowers throughout the life span leading to more number of fruits which has ultimately contributed to the highest yield in $\mathrm{T}_{13}$. These findings are in congruence with the findings of Anjanappa et al., (2012) in cucumber, Thriveni et al., (2017) in bitter gourd, Patle et al., (2018) and Singh et al., (2018) in cucumber.

However, the inferior response in $\mathrm{T}_{8}$ may be related to the inadequate supply of nutrients from bulky organic manure like FYM having low analytical value as compared to vermicompost. Integration of inorganic fertilizers with FYM @ 30 t/ha without inoculating with biological components like Azotobacter and PSB might have contributed to the inefficient utilization of nutrients. Results are in consonance with the findings of Arisha et al., (2003) in pepper, Jilani et al., (2009) and Arshad et al., (2014). As they are the major factor responsible for converting the unavailable form to available form through nitrogen fixation and phosphorus solubilisation in soil. Absence of these biological components has resulted in reduction of soil biological activity thereby decreasing the rate of decomposition of organic manure and resulting in poor supply of nutrients to the vines. North eastern soils are acidic in nature where the available forms of phosphorus supplied through inorganic fertilizer are readily converted to insoluble forms due to the abundance of $\mathrm{Al}^{3+}$ and $\mathrm{Fe}^{3+}$ ions in low $\mathrm{pH}$ condition.

This might be one of the factors responsible for poor utilization of nutrients especially phosphorus when they are applied without integration with biological components. Inferior yield in $\mathrm{T}_{8}$ may be attributed to poor uptake of nutrients due to the lack of additional application of Azotobacter and PSB which are the beneficial microorganisms mediating nitrogen fixation and phosphorus solubilisation especially in acidic soil. The results are in consonance with Kolkar et al., (2016) and Saravaiya et al., (2012) in pointed gourd.

Integration of inorganic fertilizers with vermicompost and biofertilizers has provided the impeccable growing media with favourable soil physical, chemical and biological environment. Initial nutrient requirement of the vines had been fulfilled through the application of $50 \%$ of inorganic fertilizers which are known to supply nutrients immediately leading to vigorous vegetative growth while the remaining 50\% of requirements was supplemented through organic manure and microbial inoculants which had slowly satisfied the nutrient requirement of the vine at later stages of the growth mainly during fruit development. Hence, the supplement of nutrients through both inorganic and organic sources had conjointly helped the vines to produce higher yield with superior quality. Further, integration of organic manures, inorganic fertilizers and biofertilizers is the best alternative as it ensures high yield of produce 
with enhanced fruit quality without in anyway hampering the ecological balance. It was evident from the experimental findings that integrated nutrient management approach can efficiently fulfil the nutrient requirement of cucumber thereby reducing the heavy application of inorganic fertilizers alone. Combined application of inorganic fertilizers, organic manures and biofertilizers has increased the efficacy of applied nutrient in the soil.

Integration of vermicompost with inorganic fertilizers and microbial inoculants has efficiently contributed in mineralisation of unavailable forms of nutrient to the available form. Biofertilizers like Azotobacter and PSB has provided aids in solubilisation and translocation of nutrients to the vines further resulting in high yield with enhanced fruit quality. Furthermore, vitamins, minerals, plant growth regulators and native microbial population present in vermicompost have rendered beneficial effect in accelerating the rate of decomposition and faster release of nutrients to the vines. From the present investigation, it was concluded that the integration of $50 \%$ of RDF of NPK + vermicompost@5t/ha + Azotobacter@5 kg/ha + PSB @ 5 kg/ha was witnessed to be the best INM approach for protected cultivation of cucumber under Pasighat condition.

\section{References}

Anjanappa, M., Kumara, B.S. and Indiresh, K.M. (2012). Growth, yield and quality attributes of cucumber ( $c v$. Hassan Local) as influenced by integrated nutrient management grown under protected condition. Mysore J. Agric. Sci., 46(1): 32-37.

Arisha, H.M.E., Gad, A.A. and Younes, S.E. (2003). Response of some pepper cultivars to organic and mineral nitrogen fertilizer under sandy soil conditions. $J$.
Agric. Res., 30: 1875-1899.

Arshad, I., Ali, W. and Khan, Z.A. (2014). Effect of different levels of NPK fertilizers on the growth and yield of greenhouse cucumber (Cucumis sativus L.) by using drip irrigation technology. Int. J. Res., 1(8): 650-660.

Arun, R. and Kumar, R.J. (2014). Influence of nutrient management system on yield attributes of cucumber (Cucumis sativus L. var. Beit Alpha) cultivated in polyhouse conditions. Trends in Biosci., 7(21): 3450-3452.

Baghel, S.S., Bose, U.S. and Singh, S.S. (2017). Impact of different organic and inorganic fertilizers on sustainable production of bottle gourd [Lagenaria siceraria L.]. Int. J. Pure App. Biosci., 5(2): 1089-1094.

Bailey, L.H. (1929). The domesticated cucurbits. J. Genets. Herb., 2: 62

Bhuma, M. (2001). Studies on the impact of humic acid on sustenance of soil fertility and productivity of greengram (VBNGG2). M.Sc. Thesis, Submitted to Tamil Nadu Agricultural University, Coimbatore, India.

Bindiya, Y. (2004). Integrated nutrient management in cucumber (Cucumis sativus L.). M.Sc. Thesis, Submitted to Acharya N.G. Ranga Agricultural University, Hyderbad, India.

Dinesh, M. and Yadav, V.P. (2000). Mitigating soil pollution through integrated nutrient management system. Bioved, 11(1/2): 7577.

Eifediyi, E.K. and Remison, S.U. (2010). Growth and yield of cucumber (Cucumis sativus L.) as influenced by farmyard manure and inorganic fertilizer. J. Plant Breed. Crop Sci., 2(7): 216-220.

Ghasem, S., Morteza, A.S. and Maryam, T. (2014). Effect of organic fertilizers on cucumber (Cucumis sativus L.) yield. Int. J. Agric. and Crop Sci., 7(11): 808.

Ghayal, R.G., Vaidya, K.P. and Dademal, A.A. (2018). Effect of different organic and inorganic fertilizers on growth and yield of cucumber (Cucumis sativus L.) in lateritic soil of Konkan (M.S.). Int. J. 
Chem. Stud., 6(2): 3452-3454.

Gomez, A.K. and Gomez, A.A. (2010). Statistical procedures for agricultural research, $2^{\text {nd }}$ edn. Wiley India Private Limited, New Delhi, pp. 134-138.

Isfahani, F.M. and Besharati, H. (2012). Effect of biofertilizers on yield and yield components of cucumber. J. Biol. Earth Sci., 2(2): 83-92.

Jilani, M.S., Bakar, A. K., Waseem, A. and Kiran, M. (2009). Effect of different levels of NPK on the growth and yield of cucumber (Cucumis sativus L.) under the plastic tunnel. J. agric. soc. sci., 5(3): 99101.

Johan, P.S., George, M. and Senthil, S. (2001). Integrated nutrient management. Kisan World, 28(12):27-28.

Kameswari, P.L., Narayanamma, M., Ahmed, S.R. and Chaturvedi, A. (2010). Influence of integrated nutrient management in ridge gourd (Luffa acutangular (Roxb.) L.). Veg. Sci., 37(2): 203-204.

Kolkar, M.V., Bhosle, P.K., Deo, M.S. and Bhutada, S.A. (2016). Phosphate solubilising bacteria and their role in plants. Int. J. multidiscip. stud., 3(1): 3947.

Kumar, M., Chaudhary, V., Naresh, R.K., Maurya, O.P. and Pal, S.L. (2018). Does integrated sources of nutrients enhance growth, yield, quality and soil fertility of vegetable crops? Int. J. Curr. Microbiol. App. Sci., 7(6): 125-155.

Mahmoud, E., EL-Kader, N.A.., Robin, P., Akkal-Corfini, N. and El-Rahman L.A. (2009). Effects of different organic and inorganic fertilizers on cucumber yield and some soil properties. World J. Agric. Sci., 5: 408- 414.

Mohan, L., Singh, B.K., Singh, A.K., Moharana, D.P., Kumar, H. and Mahapatra, A.S. (2016). Effect of integrated nutrient management on growth and yield attributes of cucumber (Cucumis sativus L.) cv. Swarna Ageti under polyhouse conditions. Bioscan, 12(1): 305-308.

Moharana, D.P., Mohan, L., Singh, B.K., Singh,
A.K., Kumar, H. and Mahapatra, AS. (2017). Effect of integrated nutrient management on growth and yield attributes of cucumber (Cucumis sativus L.) $c v$. Swarna Ageti under polyhouse conditions. The Bioscan, 12(1):305-308.

Mulani, T.G., Musmade, A.M., Kadu, P.P. and Mang- ove, K.K. (2007). Effect of organic manures and bio-fertilizer on growth, yield and quality of bitter gourd (Memordica charantia L.) $c v$. Phule Green Gold. J. oil Crops, 17: 258-261.

Narayanamma, M., Chiranjeevis, C.H., Ahmed, R. and Chaturvedi, A. (2010). Influence of integrated nutrient management on the yield, nutrient status and quality of cucumber (Cucumis sativus L.). Veg. Sci., 37(1): 61-63.

Nayak, D.A., Pradhan, M., Mohanty, S., Parida, A.K. and Mahapatra, P. (2016). Effect of integrated nutrient management on productivity and profitability of pointed gourd (Trichosanthes dioica Roxb.). J. Crop Weed, 12(1): 25-31.

Patle, B.J., Wagh, A.P., Umbarkar, P.S. and Bondre, S.V. (2018). Integrated nutrient management studies in bottle gourd. $J$. Pharmacogn. Phytochem., 7(5): 13831385.

Prabhu, M., Natarajan, S., Srinivasan, K. and Pugalendhi, L. (2006). Integrated nutrient management in cucumber. Indian $J$. Agric. Res., 40(2): 123-126.

Prasad, P.H., Mandal, A.R., Sarkar, A., Thapa, U. and Mality, T.K. (2009). Effect of biofertilizer and nitrogen on growth and yield attributes of bitter gourd (Momordica charantia L.). Proceedings, International Conference on Horticulture2009, 738-740.

Rathod, P., Salvi, V.G. and Jadhav, S. (2018). Growth, yield and quality of ridge gourd as influenced by integrated nutrient management in coastal region of Maharashtra. Int. J. Chem. Stud., 6(5): 2357-2360.

Rekha, C.R. and Gopalakrishnan, J.R. (2001). Effect of levels and frequencies of organic manures and inorganic fertilizers 
on growth and productivity of bitter gourd (Momordica charantia L.). South Indian Hortic., 49: 137-139.

Saravaiya, S.N., Koladiya, P.B., Desai, D.T., Patel, N.B. and Patel, J.C. (2012). Integrated nutrient management in pointed gourd (Trichosanthes dioica Roxb.) $c v$. Local under South Gujarat conditions. Internat. J. Plant Sci., 7(1): 18-22.

Sarhan, T., Ghurbat, Z., Mohammed, H. and Jiyan, A. (2011). Effect of bio and organic fertilizers on growth, yield and fruit quality of summer squash. Sarhad $J$. Agric., 27(3): 377- 383.

Selvakumar, R. (2014). Glaustas olericulture. New Vishal Publication, New Delhi, p. 77.

Shreeniwas, C.H., Muralidha, R.S. and Singarao, M. (2000). Yield and quality of ridge gourd fruits as influenced by different levels of inorganic fertilizer and vermicompost. Ann. Agric. Res., 21(2): 262-266.

Singh, D. (2013). Vegetable Science. New Vishal Publication, New Delhi, p. 233.

Singh, J., Singh, M.K., Kumar, M., Kumar, V., Singh, K.P. and Omid, A.Q. (2018). Effect of integrated nutrient management on growth, flowering and yield attributes of cucumber (Cucumis sativus L.). Int. J. Chem. Stud., 6(4): 567-572.

Singh, K.P. and Bahadur, A. (2015). Oleiriculture-ii vegetable production and improvement. Kalyani Publishers, New
Delhi, p. 160.

Singh, L. (2016). Effect of integrated nutrient management on growth, yield and quality traits of cucumber (Cucumis sativus L.) cv. Swarna Ageti under polyhouse condition. M.Sc. Thesis, Submitted to Banaras Hindu University, Varanasi, India.

Singh, V., Prasad, V.M., Kasera, S., Singh, B.P. and Mishra, S. (2017). Influence of different organic and inorganic fertilizer combinations on growth, yield and quality of cucumber (Cucumis sativus L.) under protected cultivation. J. Pharmacogn. Phytochem., 6(4): 1079-1082.

Sreenivas, C., Muralidhar, S., Rao, M.S. (2000). Vermicompost: A viable component of IPNSS in nitrogen nutrition of ridge gourd. Ann. Agril. Res., 21: 108-113.

Thriveni, V., Mishra, H.N., Mandal, P., Chhuria, S. and Biswal, M. (2017). Influence of integrated nutrient management on yield, secondary nutrients content and uptake of bitter gourd (Momordica charantia L.). Int. J. Agri. Sci., 9(50): 4851-4853.

Vishwakarma, S.K., Gautam, D.S., Yadav, N.S. and Gautam, S.S. (2007). Effect of different levels of nitrogen and phosphorus on growth, yield and quality of spine gourd (Momordica dioica Roxb.). J. Multidiscip. Advance Res., 119-123.

\section{How to cite this article:}

Sudeshna Kharga, Pranabjyoti Sarma, S.D. Warade, P. Debnath, L. Wangchu, Amit Kumar Singh and Akhoki G. Simray. 2019. Effect of Integrated Nutrient Management on Growth and Yield Attributing Parameters of Cucumber (Cucumis sativus L.) under Protected Condition. Int.J.Curr.Microbiol.App.Sci. 8(08): 1862-1871. doi: https://doi.org/10.20546/ijcmas.2019.808.219 